\title{
STATISTICAL ANALYSIS OF THE PRODUCTION OF BLUESTONE FROM GRANULATES (ELEMENTARY COPPER) BY OXIDATION WITH HYDROGEN PEROXIDE MIXED WITH STOCK SOLUTION OF BLUESTONE AND SULFURIC ACID
}

\author{
DRAGOSLAV ILIĆ ${ }^{*}$ \\ ${ }^{1}$ High Medical School of Professional Studies, Ćuprija
}

\begin{abstract}
The technological process for the production of bluestone consists of three phases: the melting of waste copper in stationary flame furnaces, the granulate dissolution with sulfuric acid in the presence of the stock solvent of copper sulphate and hydrogen peroxide, and the crystallization of copper sulphate from a saturated blue stone solution in natural baths for crystallization. This paper describes the production of bluestone using hydrogen peroxide as an oxidation agent in a mixture of sulfuric acid and a stock solution of copper sulphate as well as the statistical description and graphic representation of the dissipation of copper $\mathrm{Cu}$ in (\%), lead $\mathrm{Pb}$ in (\%) and nickel $\mathrm{Ni}$ in (\%) in the production of copper sulphate. On the basis of the statistical analysis, the value of copper $\mathrm{Cu}$ in (\%) ranged from 70.3 to $99.78 \%$, with an arithmetic mean of $91.88800 \%$, which shows that the value of copper only in point 4 was below $80 \%$.
\end{abstract}

Keywords: Bluestone, Copper, Copper sulphate, Oxidation.

\section{INTRODUCTION}

The most important copper salt is copper sulphate of the chemical formula $\mathrm{CuSO}_{4} \mathrm{X} 5 \mathrm{H}_{2} \mathrm{O}$.

The crystalline form of bluestone is blue, which comes from the presence of 5 molecules of water. The crystalline water is easily lost by heating. At $100^{\circ} \mathrm{C}$ blue crystals lose 4 molecules of water, and at $230^{\circ} \mathrm{C}$ the last water molecule is lost and a white anhydrous salt is formed, which is very hydrophobic and absorbs water from the atmosphere, and again turns into blue crystallohydrate (Aufl 11 Band, 1960).

Blue stone is used mostly as an additive for the synthesis of premixes for fodder, it is also used as an ore flotation reagent, as well as raw material for the production of other copper salts used as plant protection agents such as: base copper carbonate, copper oxychloride, bacroxysulphate.

Research of physical-chemical properties of copper and copper nanoparticles is given in papers (Chen et al., 2014, Gavriluta et al., 2017, Hu et al., 2017, Kaluđerović-Radoičić et al., 2015, Meng et al., 2016, Vlcek \& Pohanka, 2018, Zuev et al., 2016).

\section{THEORETICAL PART}

For the production of bluestone, copper of different quality and origin is used, sulfuric acid, solvents and oxidation agents.
The technological process itself can be classified into three phases:

First phase: Melting of waste copper in stationary flame furnaces. This phase also includes purifying the copper from a impurities such as iron, tin, lead, nickel, cadmium, selenium zinc and aluminum. Purification yields a pure copper granulate.

Second phase: The dissolution of the granulate with sulfuric acid in the presence of the stock solution of copper sulfate, and an oxidizing agent with heating.

Third phase: Crystallization of bluestone from a saturated solution of bluestone in natural way in baths for crystallization.

The following tasks are foreseen in this paper:

- The dissolution of granulates or elementary copper in diluted acid in the presence of oxygen as an oxidizing agent takes place very slowly, the oxidation lasts for 20 days at a temperature of $80^{\circ} \mathrm{C}$. In this paper, we took a stronger oxidizing agent hydrogen peroxide of the concentration of $20 \%$ of the technical quality. The quantity of hydrogen peroxide added is $30 \%$ of the total weight of spraying solution. We controlled how long the reaction is accelerating and how much is shorter the dissolution time of the granules in the presence of peroxide. Analyze copper granulates on the content of copper, iron, lead, cadmium, tin, zinc and aluminum.

- Performing an analysis of copper slag resulting from the process of refining the copper on the same metals.

- Conducting the analyses of the finished product on the contents of the same elements.

\footnotetext{
* Corresponding author: dragoslavilicks@gmail.com
} 


\section{EXPERIMENTAL PART}

The experimental part of this paper was done at the factory CI Župa from Kruševac.

Approximately 7 tons of granulates previously measured on a technical scale are inserted in a $7.5 \mathrm{~m}^{3}$ tower. The dilution of the granulates is done with a diluted sulfuric acid of $200 \mathrm{~g} / \mathrm{l}$ concentration. The sulfuric acid used is of a technical quality. About $20 \%$ of the stock blue stone solution (which remained from the previous production) is added to the solution, the concentration of copper sulphate in the matrix is $20 \%$. The matrix density is $\rho=1.20 \mathrm{~g} / \mathrm{cm}^{3}$.

Also, about $20 \%$ of hydrogen peroxide was added, of the technical quality and of the concentration about $35 \%$

After batching and preparation of the spraying solution, the granulate is heated with water vapor through the ejector at a temperature of $80^{\circ} \mathrm{C}$. After reaching the temperature, the spraying of the granulates is started. The dosing of the solution is continuous and is carried out by free fall through the Segner

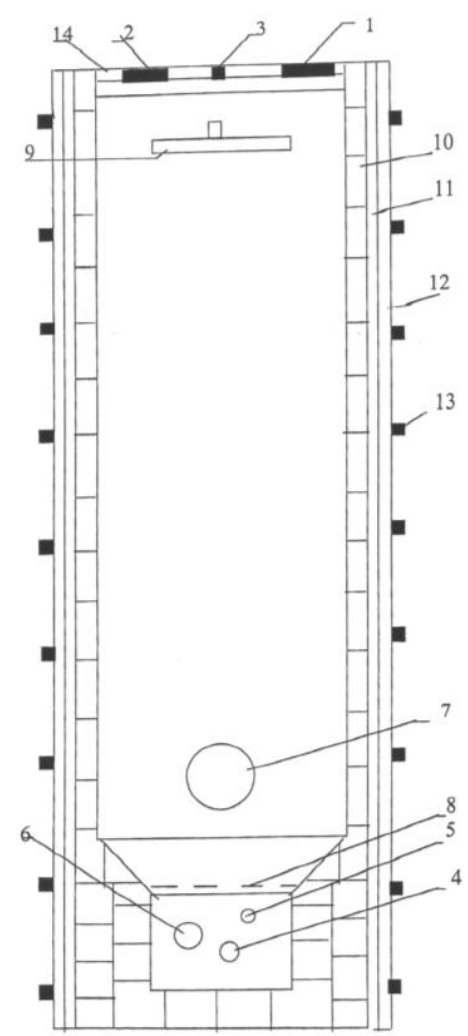

1. Opening for granulate batching

2. Vapor drainage hole

3. Opening for dosing the spraying solution

4. Opening for solution outlet

5. Opening for ejector

6. Opening for cleaning the basin

7. Opening for cleaning the tower

8. Perforated bottom

9. Segner's wheel

10.Tower building

11.Lead sheet

12. Wooden racks

13. Steel hoops

14.Stainless steel cover
Figure 1. The tower for the production of a blue stone solution.

The role of copper sulphate from the stock that is mixed with the sulfuric acid solution and the hydrogen peroxide is to convert the cuprous sulphate into cupric sulphate:

$$
\begin{aligned}
& \mathrm{CuSO}_{4}+\mathrm{Cu} \leftrightarrow \mathrm{Cu}_{2} \mathrm{SO}_{4} \\
& \mathrm{CuSO}_{4}+\mathrm{CuO}+\mathrm{H}_{2} \mathrm{O} \leftrightarrow \mathrm{Cu}_{2} \mathrm{O}+\mathrm{H}_{2} \mathrm{SO}_{4}+\mathrm{O} \\
& \mathrm{Cu}_{2} \mathrm{O}+\mathrm{H}_{2} \mathrm{SO}_{4} \leftrightarrow \mathrm{Cu}_{2} \mathrm{SO}_{4}+\mathrm{H}_{2} \mathrm{O} \\
& \mathrm{Cu}_{2} \mathrm{SO}_{4}+\mathrm{H}_{2} \mathrm{SO}_{4}+\mathrm{O} \leftrightarrow 2 \mathrm{CuSO}_{4}+\mathrm{H}_{2} \mathrm{O}
\end{aligned}
$$

The reaction is exothermic and the temperature of the reaction is increased by the presence of hydrogen peroxide, which causes a lower energy consumption and increases the rate of dissolution of the granulates, thus reducing the technological process of producing blue stone (Kirk-Othner, 1965).

The rate of dissolution of copper granules, that is, the rate of copper sulphate production depends on several factors: 
The size of the surface of the copper granulate and the spraying solution. The maximum contact surface is achieved if the granules are hallow with as thin walls as possible.

From the presence of $\mathrm{H}_{3} \mathrm{O}^{+}$ions in solution. By examining the conductivity of the sulfuric acid solution and the dissolved copper sulphate solutions, it was found that the maximum presence of $\mathrm{H}_{3} \mathrm{O}^{+}$ions is between $130-160 \mathrm{~g} / \mathrm{l}$ of sulfuric acid (Jovanović \& Jovanović, 1970).

From the rate of diffusion of hydrogen ions from sulfuric acid. The diffusion velocity at the stationary solutions is for each agent one constant. It can be increased by initiating a solvent or solute or by initiating both reaction subjects. All of this relates to the condition of the complete contact of the reactants. When dissolving the copper granulate, the solution for dissolution moves through the Segner wheel and further movement from the top to the bottom of the tower by free fall, i.e. by gravity, passing over the granules of copper with which the tower is filled and which is immobile. In this way, the maximum speed is reached, beyond which the higher speed does not produce a greater effect.

From the coating of copper granules with sludge, which is separated during the dissolution of granules derived from sulfuric acid and copper granulates. This phenomenon reduces the rate of dissolution of copper granules because the created sludge isolates the granules from the solvents. The partial removal of sludge during operation of the tower is done by closing the valve a solution of copper sulphate solution, where the level of the solution in the tower is lifted and the granules are sunk, and the water vapor flowing through the tower rinses the settled sludge (Dibina, 1962, Vssermanm, 1962).

\section{RESULTS AND DISCUSION}

The density of the solution from the towers which flows into the collecting basins which are heated with steam is 1.36$1.40 \mathrm{~g} / \mathrm{cm}^{3}$. The content of copper sulphate is $680-700 \mathrm{~g} / \mathrm{l}$ containing 5-10 g/l of free sulfuric acid. This solution, as mentioned earlier, goes into the sedimentation tanks built of reinforced concrete, clad with steel sheets and resistant to sulphates. Sedimentation tanks are heated by the respective heaters through which water vapor is flowing to maintain a temperature of 80 degrees. Upon standing of the solution in the reservoirs, the solution is purified by settling the impurities. From the solution, a higher density of $1.46 \mathrm{~g} / \mathrm{cm}^{3}$ is achieved by heating the solution, which enables the rapid crystallization of the blue stone. The precipitation of the solution is about 24 hours. This solution is transported by free fall into baths for crystallization of blue stone. This is natural crystallization and the time depending on the temperature is 10 to 15 days.

Table 1 shows the results of the analysis of the used granulate for the production of blue stone, and Table 2 a statistical description of the data from Table 1 is shown.

Table 1. Results of the analysis of the used granulate for the production of blue stone

\begin{tabular}{|c|c|c|c|c|c|c|c|c|}
\hline No. & $\mathrm{Cu}(\%)$ & $\mathrm{Fe}(\%)$ & $\mathrm{Pb}(\%)$ & $\mathrm{Ni}(\%)$ & $\mathrm{Cd}(\mathrm{pmm})$ & $\mathrm{Sn}(\%)$ & $\mathrm{Zn}(\mathrm{pmm})$ & $\mathrm{Al}(\mathrm{pmm})$ \\
\hline 1 & 87.81 & 0.033 & 0.4985 & 0.0795 & 3.8 & $/$ & 95 & 39 \\
\hline 2 & 97.82 & 0.005 & 0.1711 & 0.0232 & $/$ & $/$ & 67 & 20 \\
\hline 3 & 90.70 & 0.004 & 0.7336 & 0.1753 & 2.2 & $/$ & 33 & 44 \\
\hline 4 & 70.30 & 0.003 & 0.5729 & 0.1051 & $/$ & 0.0485 & 42 & 66 \\
\hline 5 & 83.49 & 0.005 & 1.1899 & 0.0600 & $/$ & 0.0775 & 75 & 22 \\
\hline 6 & 97.94 & 0.002 & 0.2975 & 0.0179 & 2.3 & 0.0070 & 50 & 70 \\
\hline 7 & 99.65 & 0.002 & 0.712 & 0.1215 & 1.6 & 0.0144 & 41 & $/$ \\
\hline 8 & 89.91 & 0.003 & 0.1788 & 0.0598 & 3.9 & 0.0137 & 41 & 40 \\
\hline 9 & 94.72 & 0.004 & 0.8537 & 0.0510 & 6.1 & 0.0245 & 60 & 20 \\
\hline 10 & 99.09 & 0.004 & 0.4140 & 0.0250 & 6.6 & 0.0234 & 77 & 44 \\
\hline 11 & 99.78 & 0.004 & 0.8845 & 0.0313 & $/$ & 0.0290 & 70 & 37 \\
\hline 12 & 92.05 & 0.005 & 0.3570 & 0.0196 & 4.2 & 0.0125 & 48 & 21 \\
\hline 13 & 91.93 & 0.003 & 0.5883 & 0.0547 & $/$ & 0.0201 & 60 & $/$ \\
\hline 14 & 84.55 & 0.002 & 0.2602 & 0.0123 & 12.5 & 0.0146 & 33 & $/$ \\
\hline 15 & 98.5 & 0.003 & 1.1388 & 0.1040 & $/$ & 0.0161 & 54 & 40 \\
\hline 16 & 95.03 & 0.004 & 1.2403 & 0.0242 & $/$ & 0.0196 & 67 & $/$ \\
\hline 17 & 96.69 & 0.006 & 0.4158 & 0.0191 & 22.2 & 0.0121 & 111 & 40 \\
\hline 18 & 82.71 & 0.009 & 0.8493 & 0.0484 & 8.4 & 0.0315 & 103 & 42 \\
\hline 19 & 93.36 & 0.002 & 2.0035 & 0.0339 & $/$ & 0.017 & 78 & $/$ \\
\hline 20 & 91.73 & 0.002 & 0.958 & 0.2485 & $/$ & 0.0178 & 39 & $/$ \\
\hline
\end{tabular}


Table 2. Statistical description of the results of the analysis of the used granulate for the production of blue stone

\begin{tabular}{|l|c|c|c|c|c|c|c|c|c|}
\hline \multicolumn{1}{|c|}{ Measures } & $\mathrm{Sign}$ & $\mathrm{Cu}(\%)$ & $\mathrm{Fe}(\%)$ & $\mathrm{Pb}(\%)$ & $\mathrm{Ni}(\%)$ & $\mathrm{Cd}(\mathrm{pmm})$ & $\mathrm{Sn}(\%)$ & $\mathrm{Zn}(\mathrm{pmm})$ & $\mathrm{Al}(\mathrm{pmm})$ \\
\hline Sample size & $\mathrm{N}$ & 20 & 20 & 20 & 20 & 20 & 20 & 20 & 20 \\
\hline Minimum & $\mathrm{Min}$ & 70.3 & 0.002 & 0.1711 & 0.0123 & 0 & 0 & 33 & 0 \\
\hline Maximum & $\mathrm{Max}$ & 99.78 & 0.033 & 2.0035 & 0.2485 & 22.2 & 0.0775 & 111 & 70 \\
\hline Range & $\mathrm{Rx}$ & 29.48 & 0.031 & 1.8324 & 0.2362 & 22.2 & 0.0775 & 78 & 70 \\
\hline Total & $\mathrm{Sum}$ & 1210.05 & 0.051 & 10.1422 & 0.7318 & 63.9 & 0.2519 & 841 & 284 \\
\hline Mean & $\mathrm{Aver}$ & 91.88800 & 0.00525 & 0.71589 & 0.06572 & 3.69000 & 0.01997 & 62.20000 & 28.68421 \\
\hline Geometric mean & $\mathrm{GM}$ & 91.58443 & 0.00388 & 0.59033 & 0.04697 & & & 58.42917 & \\
\hline Harmonic mean & $\mathrm{HM}$ & 91.25448 & 0.00334 & 0.47585 & 0.03521 & & & 54.93846 & \\
\hline Median & $\mathrm{Me}$ & 92.705 & 0.004 & 0.65015 & 0.0497 & 1.9 & 0.01655 & 60 & 37 \\
\hline Std. deviation & $\mathrm{SD}$ & 7.36174 & 0.00675 & 0.44854 & 0.06038 & 5.56340 & 0.01774 & 22.75638 & 21.95210 \\
\hline Variance & $\mathrm{Var}$ & 54.19528 & 0.00005 & 0.20119 & 0.00365 & 30.95147 & 0.00031 & 517.85263 & 481.89474 \\
\hline Coef. of variation & $\mathrm{CV}$ & 8.01165 & 128.57607 & 62.65546 & 91.88070 & 150.76978 & 88.86427 & 36.58581 & 76.53026 \\
\hline Skewness & $\mathrm{Sk}$ & -1.41867 & 4.02983 & 1.22132 & 1.84806 & 2.27596 & 1.97364 & 0.66778 & 0.10557 \\
\hline Kurtosis & $\mathrm{Ku}$ & 2.55663 & 17.12341 & 2.15899 & 3.57508 & 5.93995 & 5.32764 & -0.27350 & -0.74556 \\
\hline
\end{tabular}

The table 1 shows clearly that the heavy metal granulate contains the highest concentration of lead. Other impurities are not represented in large concentrations, which means that refining or separation of impurities by melting or refining is performed well.

Copper content was determined electrogravimetrically and all other metals on AAS (PERKIN-ELMER1100).
Primes in the melted copper are separated as an sludge that is removed from the surface of melted copper. Copper values in $\mathrm{Cu}$ granulate (\%) ranged from 70.3 to $99.78 \%$ (Fig. 2). The value of the arithmetic mean of copper $\mathrm{Cu}$ in (\%) was $91.88800 \%$, the geometric mean was $91.58443 \%$, the harmonic mean was $91.25448 \%$, the median was $92.705 \%$, and the standard deviation was 7.36174 .

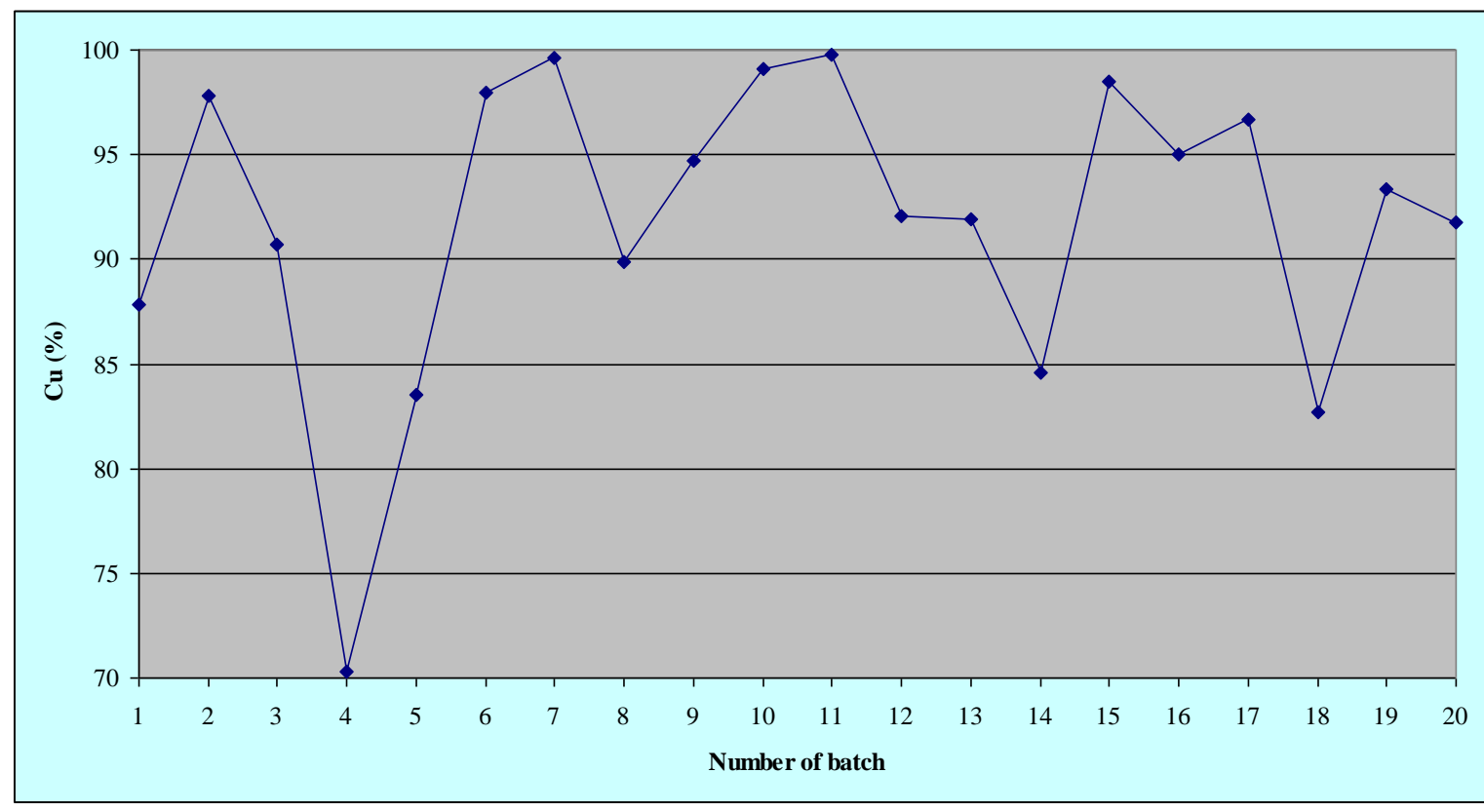

Figure 2. Graphic representation of the copper content $\mathrm{Cu}$ in (\%) in 20 successive copper granulate batches

In order to better remove the heavy metals, as the melting agent the quartz sand is added, and in addition, the air is blown into the furnace to oxidize the metal. The oxidation is also done by the oxygen crossing from the cuprous oxide to the present metals.
Metal impurities react as follows:

$$
\mathrm{Me}+\mathrm{Cu}_{2} \mathrm{O} \leftrightarrow \mathrm{MeO}+2 \mathrm{CuO}
$$

This reaction takes place until a balance is established. 
Lead is easily oxidized to $\mathrm{PbO}$. Lead oxide partially evaporates and the remaining greater part falls to the bottom of the furnace and represents the biggest problem of removal from the granules, since it is specifically heavier than copper, $\rho \mathrm{Pb}$ is $9.2 \mathrm{~g} / \mathrm{cm}^{3}$, and $\rho \mathrm{Cu}=8.3 \mathrm{~g} / \mathrm{cm} 3$, for this reason it is very difficult to remove the lead from melted copper, which is manifested by increased lead content in the finished product. To completely remove lead from molten copper, we need a second melting agent. The removal of the increased content of lead is performed by adding quartz sand to the lead in the furnace before the beginning of the refining to pull the lead and leave the lead as a slag. The results are good so that the finished product contains satisfactory values.

The values of lead $\mathrm{Pb}$ in $(\%)$ ranged from 0.1711 to $2.0035 \%$ (Figure 3). The value of the arithmetic mean of lead $\mathrm{Pb}$ in $(\%)$ was $0.71589 \%$, the geometric mean was $0.59033 \%$, the harmonic mean was $0.47585 \%$, the median was $0.65015 \%$, and the standard deviation was 0.44854 .

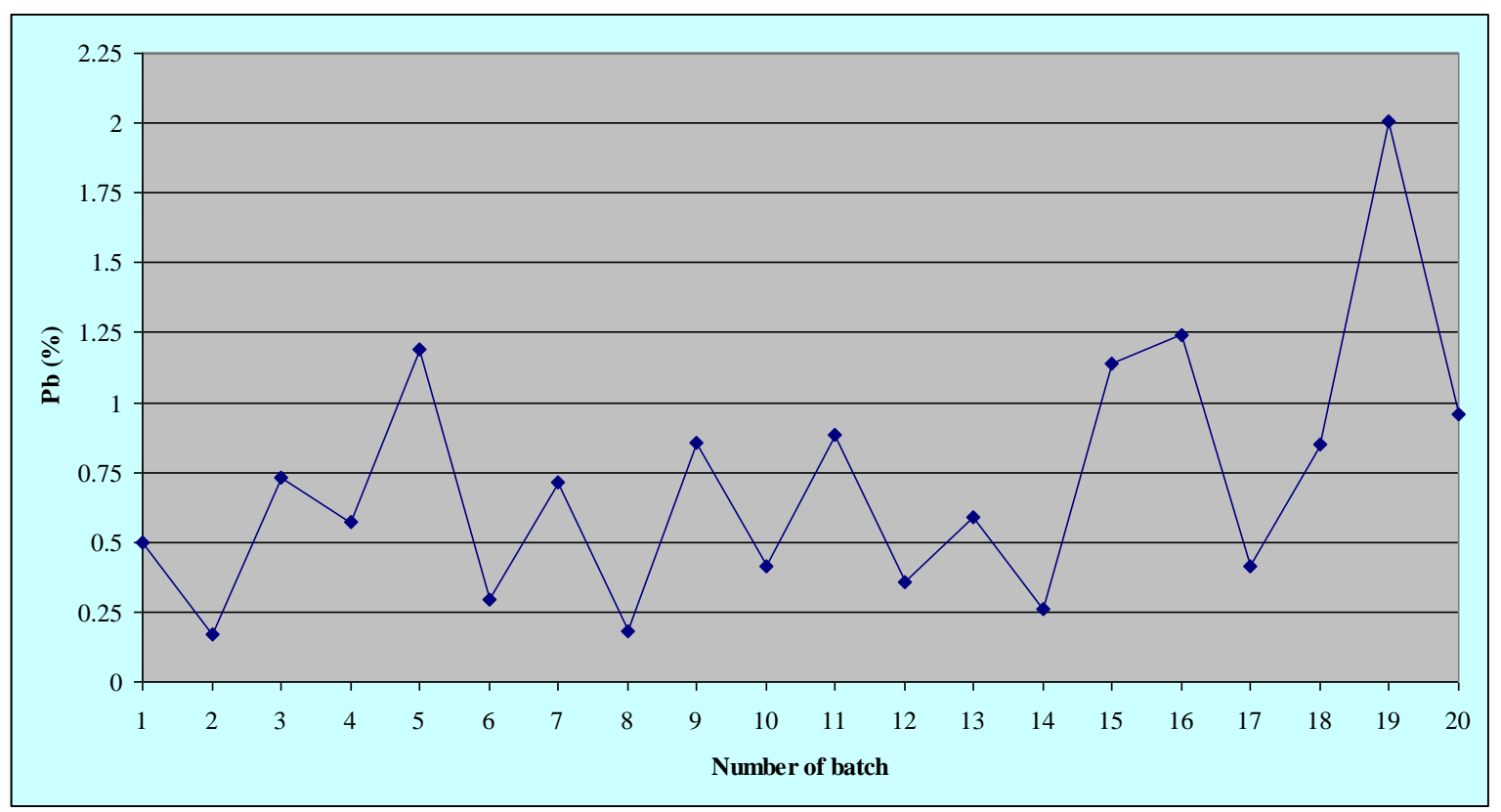

Figure 3. Graphic representation of the lead content $\mathrm{Pb}$ in (\%) in 20 successive copper granulate batches.

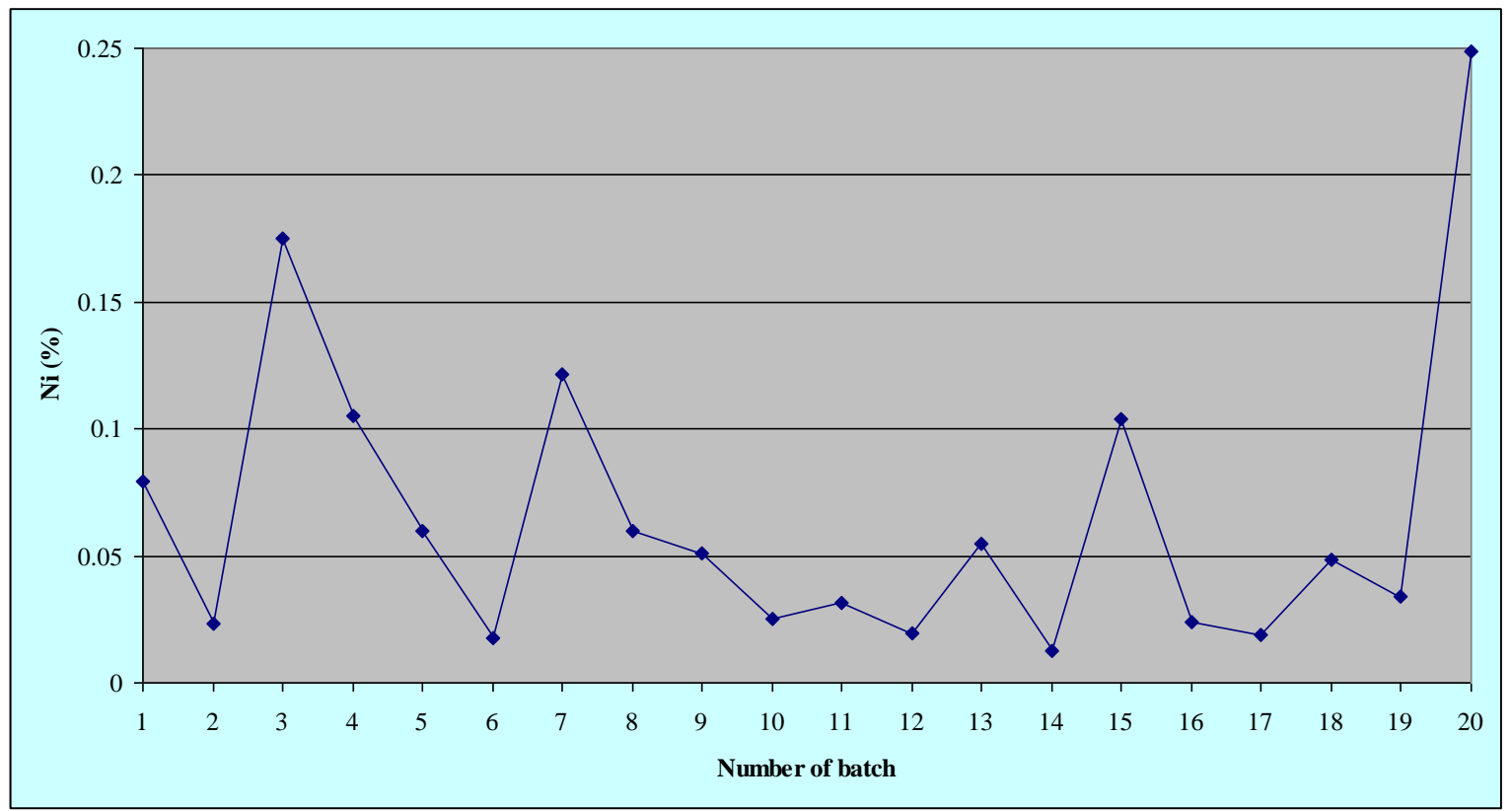

Figure 4. Graphic representation of the Nickel content $\mathrm{Ni}$ in (\%) in 20 successive copper granulate batches. 


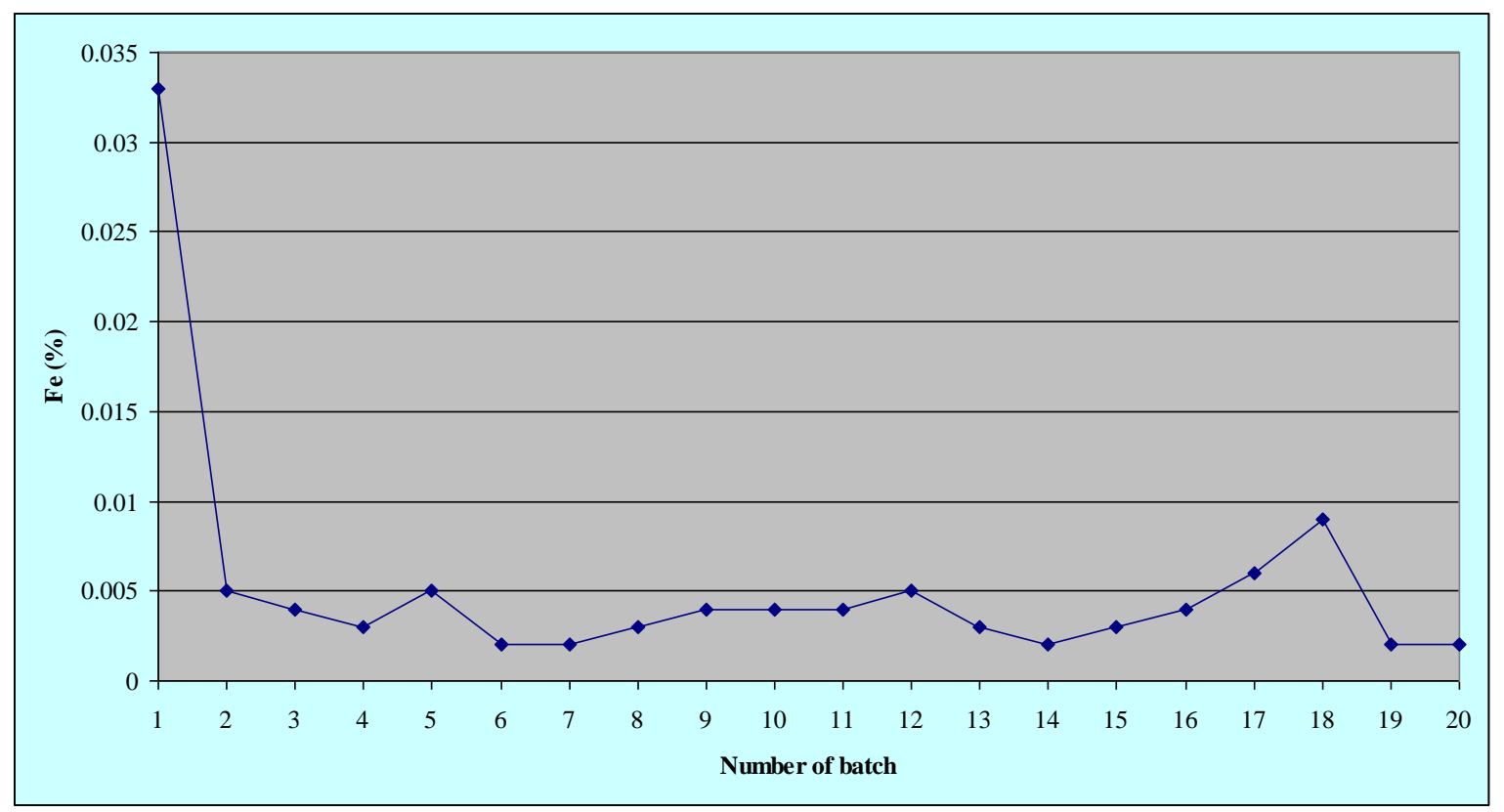

Figure 5. Graphic representation of the Ferrum content Fe in (\%) in 20 successive copper granulate batches.

The nickel values $\mathrm{Ni}$ in $(\%)$ ranged from 0.0123 to $0.2485 \%$ (Figure 4 ). The value of the arithmetic mean of nickel $\mathrm{Ni}(\%)$ was $0.06572 \%$, the geometric mean was $0.04697 \%$, the harmonic mean was $0.03521 \%$, the median was $0.0497 \%$ and the standard deviation was 0.06038 .

TIron ferrum values $\mathrm{Fe}$ in (\%) ranged from 0.002 to $0.033 \%$ (Figure 5). The value of the arithmetic mean of Ferrum, $\mathrm{Fe}$ in $(\%)$ was $0.00525 \%$, the geometric mean was $0.00388 \%$, the harmonic mean was $0.00334 \%$, the median was $0.004 \%$, and the standard deviation was 0.00675 .

Table 3. The content of copper and other impurities in the slag

\begin{tabular}{|c|c|c|c|c|c|c|c|c|}
\hline No. & $\mathrm{Cu}(\%)$ & $\mathrm{Fe}(\%)$ & $\mathrm{Pb}(\%)$ & $\mathrm{Ni}(\%)$ & $\mathrm{Cd}(\mathrm{ppm})$ & $\mathrm{Sn}(\%)$ & $\mathrm{Zn}(\%)$ & $\mathrm{Al}(\%)$ \\
\hline 1 & 17.51 & 15.34 & 0.793 & 0.09 & 6.1 & 1.133 & 2.173 & 0.86 \\
\hline 2 & 7.83 & 28.08 & 0.074 & 0.12 & $/$ & $/$ & 0.95 & 0.84 \\
\hline 3 & 16.39 & 6.287 & 1.153 & 0.11 & $/$ & 1.01 & 1.33 & 1.46 \\
\hline 4 & 5.655 & 4.05 & 0.04 & 0.01 & $/$ & 0.055 & 0.186 & 0.23 \\
\hline 5 & 18.06 & 18.81 & 0.22 & 0.07 & 4.6 & 0.186 & 0.245 & 1.77 \\
\hline 6 & 46.0 & 17.92 & 4.55 & 0.29 & 25.0 & 3.01 & 11.11 & 0.15 \\
\hline 7 & 30.44 & 3.26 & 1.84 & 0.13 & 5.5 & 0.88 & 3.29 & 0.19 \\
\hline
\end{tabular}

As it can be seen, there is a rather great copper content in the slag. The goal is to obtain a slag with less copper content.

After finishing the process of dissolving the granules, settling the blue stone solution in the deposition tanks and achieving the density of the solution of $1.46 \mathrm{~g} / \mathrm{cm}^{3}$, the solution is transferred to natural crystallizers. The crystallisers are about 9 $\mathrm{m}^{3}$ in volume and are made of acid-resistant steel material 4574. The crystallization takes 10-15 days depending on weather conditions. Crystals obtained by natural crystallization are large, monolithic and are distributed along the walls and bottom of the
Copper slag occurs as a by-product in the production of blue stone. It is formed by forming a slag in the furnace from the melting agent and a mixture of oxides of metal and copper. It is removed from the furnace, but thereat incorporated copper is also extracted.

Table 3 gives the content of copper and other impurities in the slag.

bath. After the completion of the crystallization process, the syphoning of the stock solution above the crystals is carried out and put into special reservoirs.

After that the crystals are removed from the bath and centrifuged. Centrifuge is vertical by type. It consists of an outer drum that collects the stock solution, the conical shutter for emptying, the braking mechanism. The centrifuge operation is discontinuous (batched).

The centrifugation time depends on the amount of moisture and free sulfuric acid we want to have in the finished product, 
usually the centrifugation time is about $30 \mathrm{~min}$. Together with centrifuging, the washing of crystals with communal water is done.

After the completion of the centrifugation process, natural drying of the crystals of blue stone is done. Given the increasing commercial demands that the moisture content of the crystal is kept as small as possible (0.05-0.07\%), we dry the crystal for so long and in the final product we have obtained moisture in this range.

After the completion of the drying process, we made an analysis of the blue stone (finished product) to the following parameters from several samples.

Table 4 gives some results of the analysis of the finished product from the warehouse.

Table 4. Results of the analysis of the finished product from the warehouse

\begin{tabular}{|c|c|c|c|c|c|c|c|c|c|c|c|}
\hline No. & $\begin{array}{c}\mathrm{CuSO}_{4} 5 \mathrm{H}_{2} \mathrm{O} \\
(\%)\end{array}$ & $\mathrm{Fe}(\mathrm{ppm})$ & $\mathrm{Pb}(\mathrm{ppm})$ & $\mathrm{Ni}(\mathrm{pmm})$ & $\begin{array}{c}\mathrm{Cd} \\
(\mathrm{pmm})\end{array}$ & $\mathrm{Al}(\mathrm{pmm})$ & $\mathrm{Zn}(\mathrm{pmm})$ & $\mathrm{Sn}(\mathrm{pmm})$ & As (pmm) & $\begin{array}{l}\text { slobodna } \\
\mathrm{H}_{2} \mathrm{SO}_{4} \mathrm{~K}\end{array}$ & Vlaga (\%) \\
\hline 1 & 98.74 & 297 & 40.0 & 25.0 & 0.8 & 7.9 & 62.4 & 15.8 & I & 0.05 & 0.5 \\
\hline 2 & 99.11 & 299 & 85.0 & 35.2 & 1.4 & 19.9 & 51.8 & 27.9 & I & 0.06 & 0.6 \\
\hline 3 & 98.11 & 297 & 90.0 & 25.9 & 1.4 & 7.8 & 62.4 & 15.8 & I & I & 0.65 \\
\hline 4 & 99.60 & 200 & 68.0 & 35.4 & 0.7 & 9.9 & I & 1 & I & 0.07 & 0.63 \\
\hline 5 & 99.07 & 337 & 74.9 & 56.0 & 1.0 & I & 69 & 19.7 & 0.23 & 0.06 & 0.64 \\
\hline 6 & 99.12 & 297 & 78.6 & 70.5 & 0.8 & I & I & I & I & 0.065 & 0.7 \\
\hline 7 & 99.05 & 269 & 85.0 & 73.4 & 0.7 & I & I & I & 0.22 & 0.03 & 0.55 \\
\hline 8 & 99.12 & 180 & 91.0 & 89.0 & 0.8 & I & / & I & 0.20 & I & 0.5 \\
\hline 9 & 99.23 & 170 & 66.0 & 90.0 & 0.8 & I & I & I & 0.21 & I & 0.4 \\
\hline
\end{tabular}

Quality control of the finished product was done at each $5 \mathrm{t}$ of finished product.

The analysis of the content of blue stone (copper) was performed by electrogravimetry and titration with thiosulphate (iodometric).

The heavy metal analysis was performed on the atomic absorption spectrophotometer (perkin -elmer)

Mercury is analyzed on AAS using hydride technique.

Free sulfuric acid analysis was performed by titration with sodium hydroxide.

The moisture content was carried out by drying at a temperature of $105{ }^{\circ} \mathrm{C}$ (gravimetrically).

\section{CONCLUSION}

In this paper, we have demonstrated that using hydrogen peroxide at a concentration of $20 \%$ as the oxidation agent mixed with a sulfuric acid solution of $200 \mathrm{~g} / \mathrm{l}$ of the stock blue stone solution ( $25 \%$ of blue stone) results in a very rapid dissolution of the granulates than when the oxidation is carried out only with oxygen. This results in a significantly shorter duration of the reaction -instead of 20 days the reaction per tower was been completed within 10 days.

The shorter time of dissolving granulates has a huge significance in the energy-fluids saving, water vapor, and therefore the time of production of blue stone is significantly reduced.

The solution obtained by dissolving the granulate is of substantially better quality than the solution obtained without the presence of peroxide. Using peroxide we do not have an insoluble residue when dissolving the granulates, which results in a significantly shorter time of settling, i.e. clarification of the solutions in the precipitators, the foreign ions do not penetrate using peroxide solution to contaminate the solution.

The amount of sludge at the bottom of the basin is considerably smaller, which is very important because the deposit is an ecological problem that the plant has to solve.

It is most important that the quality of the finished product of blue stone is satisfactory.

The table shows that all parameters meet the requirements that are stickt and that such a blue stone can be used as an additive for the preparation of premixes for fodder.

In the final product, we have slightly increased lead content compared to other metals, but the results are within reasonable limits, which resulted from the suggestion that, before each refining at the very bottom of the flame furnace, a small amount of the silicon dioxide solvent is added, which leads the lead as a heavier metal than copper at the surface of melted copper.

\section{REFERENCE}

Chen, H., Zheng, X., Chen, Y., Li, M., Liu, K., \& Li, X. 2014. Influence of Copper Nanoparticles on the Physical-Chemical Properties of Activated Sludge. PLoS One, 9(3), p. 92871. doi:10.1371/journal.pone.0092871

Dibina, P.V. 1962. Tehnologija mineralnih solej.Goshimizdat, pp. 448-471.

Gavriluta, A., Fix, T., Nonat, A., Slaoui, A., Guillemoles, J., \& Charbonnière, L.J. 2017. Tuning the chemical properties of europium complexes as downshifting agents for copper indium gallium selenide solar cells. Journal of Materials 
Chemistry

A, 5(27),

pp.

14031-14040. doi:10.1039/c7ta02892j

Hu, S., Wu, Y., Yi, N., Zhang, S., Zhang, Y., \& Xin, X. 2017. Chemical properties of dissolved organic matter derived from sugarcane rind and the impacts on copper adsorption onto red soil. Environmental Science and Pollution Research, 24(27), pp. 21750-21760. doi:10.1007/s11356-017-9834-3

Jovanović, L.J.S., \& Jovanović, S.M. 1970. Osnovi kvalitativne hemijske analize.Beograd: Naučna knjiga.

Kaluđerović-Radoičić, T., Radović, I., Ivanović, M., Rajić, N., \& Grbavčić, Ž. 2015. Proračun i optimizacija procesa proizvodnje bakar(II)-sulfat-monohidrata iz bakar(II)-sulfatpentahidrata u sušnicama sa fluidizovanim slojem. Hemijska industrija, . Vol. 69, Issue 3, pp. 275-286.

Kirk-Othner, 1965. Encyclopedia of Chemical Tecnology. Sec.ed. vol. 6, pp. 276-278.

Meng, D., Chen, H., \& Xue, G. 2016. Interaction effects of typical PPCPs and copper nanoparticles on physical-chemical properties. Huagong Xuebao/CIESC Journal, . Vol. 67, Issue 10, pp. $4455-4460$.

Ulmanns enciklopedie der technishen Chemie 1960. Aufl 11 Band. 3. pp. 246-250.

Vlček, V., \& Pohanka, M. 2018. Adsorption of Copper in Soil and its Dependence on Physical and Chemical Properties. Acta Universitatis Agriculturae et Silviculturae Mendelianae Brunensis, 66(1), pp. 219-224. doi:10.11118/actaun201866010219

Vssermanm, I.M. 1962. Proizvodstvo mineraljnih soli.Gshimizdat, pp. 132-189.

Zuev, K.V., Perevalov, V.P., Vinokurov, E.G., Zhigunov, F.N., \& Koldaeva, T.Y. 2016. Physical-Chemical Properties of Modified Copper-Phthalocyanine and Its Aqueous Dispersions. Macroheterocycles, 9(3), pp. 250-256. doi: $10.6060 / \mathrm{mhc} 160212 \mathrm{z}$ 